\title{
Human Benzene Metabolism Following Occupational and Environmental Exposures
}

\author{
Stephen M. Rappaport ${ }^{a},{ }^{*}$, Sungkyoon Kim ${ }^{b}$, Qing Lan ${ }^{\mathrm{C}}$, Guilan Lid, Roel Vermeulen ${ }^{\mathrm{e}}$, \\ Suramya Waidyanatha ${ }^{f}$, Luoping Zhang ${ }^{a}$, Songnian Yin ${ }^{d}$, Martyn T. Smith ${ }^{a}$, and Nathaniel \\ Rothman ${ }^{\mathrm{e}}$
}

a School of Public Health, University of California, Berkeley, CA 94720, USA b School of Public Health, Seoul National University, Seoul, Republic of Korea ${ }^{\mathrm{C}}$ National Cancer Institute (NCI), National Institutes of Health (NIH), Department of Health and Human Services (DHHS), Bethesda, MD 20892, USA d Institute of Occupational Health and Poison Control, Chinese Center for Disease Control and Prevention, Beijing, China ${ }^{e}$ Institute for Risk Assessment Sciences, Utrecht University, Utrecht, The Netherlands ${ }^{f}$ Gillings School of Global Public Health, University of North Carolina, Chapel Hill, NC 27599, USA

\section{Abstract}

\begin{abstract}
We previously reported evidence that humans metabolize benzene via two enzymes, including a hitherto unrecognized high-affinity enzyme that was responsible for an estimated 73 percent of total urinary metabolites [sum of phenol (PH), hydroquinone (HQ), catechol (CA), E,E-muconic acid (MA), and $S$-phenylmercapturic acid (SPMA)] in nonsmoking females exposed to benzene at sub-saturating ( $\mathrm{ppb}$ ) air concentrations. Here, we used the same Michaelis-Menten-like kinetic models to individually analyze urinary levels of $\mathrm{PH}, \mathrm{HQ}, \mathrm{CA}$ and MA from 263 nonsmoking Chinese women (179 benzene-exposed workers and 84 control workers) with estimated benzene air concentrations ranging from less than $0.001 \mathrm{ppm}$ to $299 \mathrm{ppm}$. One model depicted benzene metabolism as a single enzymatic process (1-enzyme model) and the other as two enzymatic processes which competed for access to benzene (2-enzyme model). We evaluated model fits based upon the difference in values of Akaike's Information Criterion ( $\triangle \mathrm{AIC}$ ), and we gauged the weights of evidence favoring the two models based upon the associated Akaike weights and Evidence Ratios. For each metabolite, the 2-enzyme model provided a better fit than the 1-enzyme model with $\triangle$ AIC values decreasing in the order 9.511 for MA, 7.379 for $\mathrm{PH}, 1.417$ for $\mathrm{CA}$, and 0.193 for HQ. The corresponding weights of evidence favoring the 2-enzyme model (Evidence Ratios) were: 116.2:1 for MA, 40.0:1 for PH, 2.0:1 for CA and 1.1:1 for HQ. These results indicate that our earlier findings from models of total metabolites were driven largely by MA, representing the ring-opening pathway, and by $\mathrm{PH}$, representing the ring-hydroxylation pathway.
\end{abstract}

(C) 2009 Elsevier Ireland Ltd. All rights reserved.

"Correspondence and requests for reprints to Stephen M. Rappaport, School of Public Health, University of California, Berkeley, CA 94720-7356, USA; telephone: 510 642-4355; fax: 510 642-0427; srappaport@ berkeley.edu.

Competing Interests: S.M.R. has received consulting and expert testimony fees from law firms representing plaintiffs' cases involving exposure to benzene and has received research support from the American Petroleum Institute and the American Chemistry Council. G.L. has received funds from the American Petroleum Institute for consulting on benzene-related health research. M.T.S. has received consulting and expert testimony fees from law firms representing both plaintiffs and defendants in cases involving exposure to benzene.

Publisher's Disclaimer: This is a PDF file of an unedited manuscript that has been accepted for publication. As a service to our customers we are providing this early version of the manuscript. The manuscript will undergo copyediting, typesetting, and review of the resulting proof before it is published in its final citable form. Please note that during the production process errors may be discovered which could affect the content, and all legal disclaimers that apply to the journal pertain. 
The predicted percentage of benzene metabolized by the putative high-affinity enzyme at an air concentration of $0.001 \mathrm{ppm}$ was $88 \%$ based upon urinary MA and was $80 \%$ based upon urinary $\mathrm{PH}$. As benzene concentrations increased, the respective percentages of benzene metabolized to $\mathrm{MA}$ and $\mathrm{PH}$ by the high-affinity enzyme decreased successively to $66 \%$ and $77 \%$ at $0.1 \mathrm{ppm}, 20 \%$ and $58 \%$ at $1 \mathrm{ppm}$, and $2.7 \%$ and $17 \%$ at $10 \mathrm{ppm}$. This indicates that the putative high-affinity enzyme was active primarily below $1 \mathrm{ppm}$ and favored the ring-opening pathway.

\section{Keywords}

benzene; metabolism; toxicokinetics; biomonitoring

\section{Introduction}

Benzene is an important environmental contaminant that is present worldwide at air concentrations ranging from $\mathrm{ppb}$ in rural and urban settings to ppm in some workplaces [1;2]. Mounting scientific evidence has shown that benzene causes leukemia and probably other lymphohematopoietic cancers in humans [3;4;5] and that benzene alters blood cell counts in persons exposed below $1 \mathrm{ppm}\left(3.2 \mathrm{mg} / \mathrm{m}^{3}\right)[6]$.

The toxicity of benzene has been related to its metabolism, which is summarized in Figure 1 [7;8;9]. The initial metabolic step involves CYP oxidation of benzene to benzene oxide, which exists in equilibrium with its tautomer oxepin. Most benzene oxide spontaneously rearranges to phenol $(\mathrm{PH})$, which is either excreted or further metabolized to hydroquinone (HQ) and 1,4-benzoquinone. The remaining benzene oxide is either hydrolyzed to produce catechol (CA) and 1,2-benzoquinone or reacts with glutathione to produce $S$ -

phenylmercapturic acid (SPMA). Metabolism of oxepin is thought to open the aromatic ring, yielding the reactive muconaldehydes and $E, E$-muconic acid (MA) [10]. Human exposures to benzene at air concentrations between 0.1 and $10 \mathrm{ppm}$, result in urinary metabolite profiles with $70-85 \% \mathrm{PH}, 5-10 \%$ each of HQ, MA and CA, and less than 1\% of SPMA [11] [12].

Because essentially all humans are exposed to benzene and because benzene must be metabolized to exert toxic effects, the relationship between levels of benzene exposure and benzene metabolites is important to our understanding of potential human health risks. We used studies of benzene-exposed and control workers in China to investigate benzene metabolism over a wide range of air concentrations. Interestingly, our studies showed supralinear production of benzene-related albumin adducts at air concentrations below 1 ppm (i.e. increased exposure-specific adduct levels below $1 \mathrm{ppm}$ ) [13;14]. We followed up the adduct studies by modeling urinary levels of $\mathrm{PH}, \mathrm{HQ}, \mathrm{CA}$ and $\mathrm{MA}$ from the same benzene-exposed and control workers; again we observed supralinear effects at benzene air concentrations below $1 \mathrm{ppm}[11 ; 15 ; 16]$. Since the observed relationships between metabolite levels and benzene exposure were inconsistent with single-enzyme kinetics of benzene metabolism, we tested whether a hitherto unrecognized second enzyme might be responsible for most benzene metabolism below 1 ppm. Using Michaelis-Menten-like models, we investigated levels of total urinary benzene metabolites (the sum of PH, HQ, CA, MA, and SPMA) in a subset of workers represented by 263 nonsmoking females exposed to benzene at air concentrations between less than 0.001 and $299 \mathrm{ppm}$ [17]. Results provided strong statistical evidence favoring two metabolizing enzymes and indicated that the higher-affinity enzyme was responsible for about $73 \%$ of all benzene metabolism at nonsaturating $(\mathrm{ppb})$ air concentrations. 
In the current study, we investigated the fits of the same Michaelis-Menten-like models to the major individual metabolites PH, HQ, CA and MA in the same sample of 263 nonsmoking females. (Because the minor metabolite SPMA showed no effect of saturable formation over the full range of benzene exposures in this population [11;15;16], kinetic models were not fit to levels of urinary SPMA). The 2-enzyme model provided much better fits for levels of PH and MA but only marginally better fits for levels of HQ and CA. Furthermore, the putative high-affinity enzyme favored the ring-opening pathway, leading to production of MA, to a much greater extent than the low-affinity enzyme.

\section{Material and methods}

\subsection{Study population and sampling}

Subjects were from two cross-sectional studies of Chinese benzene-exposed and control workers carried out in Shanghai (1992) [18;19;20] and in Tianjin (2000-2001) [6;15;21]. Subject enrollment and interview procedures, exposure assessment methods, and urinary metabolite measurements in these two studies were carried out by the same group of investigators using the same procedures. Workers with occupational exposure to benzene were employed in factories where benzene was present, and control workers were exposed to airborne benzene in the general environment, as determined by measurements of urinary benzene (Tianjin controls only) [15]. (Previous studies showed that levels of urinary benzene were highly correlated with airborne benzene exposures, even at ppb air concentrations [22;23;24]). Of the nonsmoking females, there were 179 benzene-exposed and 84 control subjects with complete data (total $=263$ nonsmoking females). Summary statistics regarding benzene exposure, age, body mass index, and weight were reported [17]. Methods of sampling personal full-shift air concentrations (Model 3500 Organic Vapor Monitors, 3M, MN) and matched post-shift urine were as reported previously $[6 ; 15 ; 21 ; 25]$. Briefly, benzene was measured in air by solvent desorption followed by gas chromatography with flame ionization detection [21]. There were 161 air measurements that were either missing or below the limit of detection (nominally $0.2 \mathrm{ppm}$ ). Air concentrations were predicted for these censored and missing air samples from the corresponding levels of urinary benzene, as described previously [15]. The estimated median exposure to benzene was $0.644 \mathrm{ppm}$ with $10^{\text {th }}$ and $90^{\text {th }}$ percentile values of $0.002 \mathrm{ppm}$ and $8.97 \mathrm{ppm}$, respectively [17]. Phenol, HQ, CA, and MA and SPMA were measured as trimethylsilyl derivatives by gas chromatography-mass spectrometry [15]. Here we report results from analysis of the individual metabolites: PH, HQ, CA and MA which had previously shown effects of saturable metabolism; SPMA was excluded from analyses because saturable production of SPMA had not been detected $[11 ; 15]$. Of the 263 subjects in these analyses, 87 had repeated measurements of air and urine, making a total of 411 matched air/urine samples. The median number of repeated air and urine samples was three (range: $2-4$ ) for these 87 subjects.

\subsection{Michaelis-Menten-like models and weights of evidence}

Relationships between levels of benzene metabolites and the corresponding benzene air concentrations were examined using nonlinear regression models (implemented with the SAS procedure NLIN) as described previously for total benzene metabolites [17]. While the connection between levels of total benzene metabolites and exposure to benzene is relatively straightforward, the relationships between levels of individual metabolites and benzene exposure are somewhat more tenuous (e.g., see Figure 1), save possibly for the dominant metabolite $\mathrm{PH}$ which is nonenzymatically produced from benzene oxide. However, because we previously showed that all major metabolites, i.e. PH, MA, HQ and CA, showed evidence of saturable metabolism with increasing benzene exposure [11], it is reasonable to assume that benzene metabolism was very influential, if not rate limiting, in the production 
of each major metabolite. For this reason, we used Michaelis-Menten-like models to investigate levels of each major metabolite as a function of benzene exposure. In these models, the enzymatic velocity was replaced by the level of a given benzene metabolite $(Y)$ $(\mu \mathrm{M})$ and the substrate concentration was replaced by the air concentration of benzene $(X)$ (ppm). Each data pair $[Y, X]$ represents a benzene metabolite concentration $(\mu \mathrm{M})$ and benzene air concentration (ppm) for a given subject. The asymptotically maximum level of $Y$ (designated $Y_{\max }$ ) is analogous to $v_{\max }$, and the benzene concentration $X$ at which $Y=$ $Y_{\max } / 2$ (designated $X_{50}, \mathrm{ppm}$ ) is analogous to $K_{m}$. We also assumed a background level of each metabolite $Y_{0}(\mu \mathrm{M})$ due to endogenous and dietary sources [15;26]. Given the highly skewed levels of benzene in air and of urinary metabolites, as well as the heteroscedasticity of the data, natural $\log$ transforms of $Y$ and the independent variables were used for regression analyses. (This is an example of the transform both sides approach for stabilizing the variance in regression analyses when the relationship between two variables is either known or assumed; see, for example, [27]). We fit two Michaelis-Menten-like models to the data, one having a single enzyme and the other having two enzymes that competed for access to benzene $(X)$. The two models are given by the following expressions:

$$
\begin{gathered}
\ln (Y)=\ln \left(Y_{0}+\frac{Y_{\max } \cdot X}{X_{50}+X}\right), \\
\ln (Y)=\ln \left(Y_{0}+\frac{Y_{\max .1} \cdot X}{X_{50.1}+X}+\frac{Y_{\max .2} \cdot X}{X_{50.2}+X}\right),
\end{gathered}
$$

where subscripts ".1" and ".2" in Eq. 2 refer to the first and second enzymes, respectively. For subjects with repeated measurements $(n=87)$, estimated geometric means of air and metabolite levels were used. Initial values for $Y_{0}, Y_{\max }, X_{50}, Y_{\max .1}$, and $X_{50.1}$ were estimated from scatter plots of benzene metabolite levels versus benzene air concentrations. Since we hypothesized that enzyme- 2 would be more active than enzyme- 1 at sub-saturating benzene concentrations, initial values were assigned to $Y_{\max .2} \ll Y_{\max .1}$ and to $X_{50.2} \ll X_{50.1}$.

However, final models were not sensitive to initial values of these parameters. The estimated kinetic parameters were used to predict relationships between individual metabolite levels and benzene exposures for enzyme-1, enzyme-2, and the sum of both enzymes.

We used Akaike's Information Criterion (AIC) for judging the better fit of Eq. 1 and Eq. 2 to the data; i.e., the model with the smaller AIC was judged to provide a better depiction of the true metabolism of benzene to a given metabolite [17]. (For a detailed explanation of use of AIC for comparing across competing models, see Burnham and Anderson [28]). Let $\triangle \mathrm{AIC}$ represent the difference in AIC values between the two competing models. The associated Akaike weights for the better and worse models are $\left(w_{\text {better }}=\frac{1}{1+\exp \left(-\frac{1}{2} \Delta \mathrm{AIC}\right)}\right)$ and $\left(w_{\text {worse }}=\frac{\exp \left(-\frac{1}{2} \Delta \mathrm{AIC}\right)}{1+\exp \left(-\frac{1}{2} \Delta \mathrm{AIC}\right)}\right)$, respectively. The Akaike weights provide information about the strengths of evidence supporting the two competing models. As $\triangle \mathrm{AIC}$ gets large, $w_{\text {better }}$ approaches one and $w_{\text {worse }}$ approaches zero, indicating that the weight of evidence supporting the better model increases with $\triangle \mathrm{AIC}$ while evidence supporting the worse model decreases with increasing $\triangle \mathrm{AIC}$. The ratio of the two Akaike weights, i.e. $\frac{w_{\text {betere }} \text {, is }}{w_{\text {wer }} \text { e }}$ termed the Evidence Ratio and represents the relative likelihood favoring the better of two competing models. That is, as $w_{\text {better }}$ approaches one, the relative likelihood that the better model is superior approaches infinity. In our context, an Evidence Ratio greater than 20, say, 
would indicate extremely strong evidence favoring the better model as a depiction of the true metabolism of benzene to a particular metabolite.

All statistical analyses were performed using SAS software for Windows ver. 9.2 (SAS Institute, Cary, NC).

\section{Results}

\subsection{Scatter plots}

Figure 2 shows scatter plots of individual benzene metabolite levels for the 263 subjects versus the air concentration of benzene on the day of urine collection. At benzene concentrations below about $0.1 \mathrm{ppm}$, levels of $\mathrm{PH}, \mathrm{HQ}$ and CA primarily reflected background sources while those of MA showed evidence of both benzene exposure and background sources. The effect of benzene exposure on production of each metabolite became increasingly apparent at air concentrations above about $1 \mathrm{ppm}$, and above $100 \mathrm{ppm}$ levels of PH, HQ and MA (but not CA) showed evidence of saturation. There was a roughly 5 -fold range of levels of each metabolite at a given air concentration of benzene.

The fitted curves in Figure 2 are the mean trends for metabolite levels predicted from the estimated parameters of the 1-enzyme model (dashed curve) and the 2-enzyme model (solid curve), which are listed in Table 1. A pronounced qualitative difference in model fits was observed for MA, where the 2-enzyme model appeared to fit the data better at benzene concentrations below $1 \mathrm{ppm}$. Qualitative differences for the other metabolites (PH, HQ and CA) were less obvious.

\subsection{Evidence supporting the 1-enzyme and 2-enzyme models}

Table 2 shows values of AIC, $\triangle \mathrm{AIC}$ and the associated Akaike weights for the fits of the 1enzyme (Eq. 1) and 2-enzyme (Eq. 2) models to the air concentrations and urinary metabolite levels for the 263 nonsmoking females in our investigation. For each metabolite, AIC was smaller for the 2-enzyme model, indicating that Eq. 2 explained more of the variability of the data than Eq. 1. However, whereas the fits of the 2-enzyme model were much better than those of the 1-enzyme model for MA $(\triangle \mathrm{AIC}=9.511)$ and $\mathrm{PH}(\triangle \mathrm{AIC}=$ 7.379), the fits for HQ $(\triangle \mathrm{AIC}=0.193)$ and $\mathrm{CA}(\triangle \mathrm{AIC}=1.417)$ were only marginally better. These differences in model fit can be interpreted via the Evidence Ratios, which represent the ratios of the Akaike weights and thus reflect the relative weights of evidence supporting the 2-enzyme models for these metabolites. The Evidence Ratio for the MA models indicated that the relatively likelihood was 116.2 to 1 that the 2-enzyme model fit the data better than the 1-enzyme model. The relative likelihood favoring the 2-enzyme model was also large for PH (Evidence Ratio $=40.0$ ) but not for either CA (Evidence Ratio $=2.0$ ) or HQ (Evidence Ratio $=1.1$ ).

\subsection{Predicted metabolite contributions from two enzymes}

As shown above, our results provide extremely strong statistical evidence that the 2-enzyme model was a better predictor of levels of MA and PH than the 1-enzyme model. The curves in Figure 3 show the predicted contributions of the two enzymes toward MA and PH. Figures $3 \mathrm{~A}$ and $3 \mathrm{C}$ show background- adjusted levels of PH and MA, respectively, obtained by subtracting estimated intercepts from the predictions of 2-enzyme models at a given benzene air concentration (Table 2). Metabolite levels predicted from the two models were similar for benzene exposures in the range of about 2 to $100 \mathrm{ppm}$ but differed substantially for lower exposure concentrations, particularly for MA. The two dashed curves in Figures $3 \mathrm{~A}$ and $3 \mathrm{C}$ indicate that enzyme-1 began to saturate at a benzene concentration of $50 \mathrm{ppm}$ for MA and about $100 \mathrm{ppm}$ for PH. The curves also show that enzyme-2 began to saturate at 
about $0.03 \mathrm{ppm}$ for MA and $0.3 \mathrm{ppm}$ for $\mathrm{PH}$ and was near full saturation at $1 \mathrm{ppm}$ for MA and $10 \mathrm{ppm}$ for PH. Relative percentages of benzene metabolites attributed to the two enzymes are shown in Figures 3B and 3D. At air concentrations below $0.01 \mathrm{ppm}$, more than $85 \%$ of MA and about $80 \%$ of PH were derived from enzyme-2. At $1 \mathrm{ppm}$ of benzene, the proportions of MA and PH derived from enzyme-2 dropped to $20 \%$ and $58 \%$, respectively, and at $10 \mathrm{ppm}$ of benzene, dropped even further to $2.7 \%$ and $17 \%$, respectively.

\section{Discussion}

\subsection{Evidence for two metabolizing enzymes}

Our previous analyses of total benzene metabolites (the sum of PH, HQ, CA, MA and SPMA) provided statistical evidence favoring two (rather than one) metabolizing enzymes $($ Evidence Ratio $=15.4)$ [17]. Furthermore, the level of total benzene metabolites predicted from the 2-enzyme model (194 $\mu \mathrm{M}$ total metabolites/ppm benzene) was quite close to the value predicted from the overall rate of benzene metabolism ( $184 \mu \mathrm{M}$ total metabolites/ppm benzene), based upon independent rates of benzene uptake and urinary elimination in nonsmoking Chinese females at sub-saturating ( $\mathrm{ppb}$ ) air concentrations. Taken together, our previous results indicate that a hitherto unrecognized high-affinity enzyme was likely responsible for most benzene metabolism at air concentrations inhaled by the general public. We discount the possibility that the observed findings could be due to functionally polymorphic forms of CYP2E1, which differentially metabolize benzene in humans. Although we previously showed that workers from this study having homozygous variants of CYP2E1 1054C-T (Rs2031920, ascribed to RsaI) had significantly lower levels of urinary $\mathrm{MA}, \mathrm{PH}$, and HQ than homozygous wild types [16], the differences were only marginal at benzene air concentrations below $1 \mathrm{ppm}$, suggesting that CYP2E1 1054C-T is active primarily at higher air concentrations.

Here, we applied the Michaelis-Menten-like models to the individual benzene metabolites $\mathrm{PH}, \mathrm{HQ}, \mathrm{CA}$ and MA. These analyses provided extremely strong statistical evidence that two enzymes were responsible for metabolizing benzene to MA (Evidence Ratio $=116.2$ ) and to PH (Evidence Ratio $=40.0$ ), but not to CA (Evidence Ratio $=2.0$ ) or to HQ (Evidence Ratio $=1.1$ ). This indicates that our earlier findings regarding total benzene metabolites were driven largely by the urinary levels of MA and PH. Since PH accounts for $60 \%-90 \%$ of all benzene metabolites [11], it is not surprising that models of PH would be similar to those previously observed for the sum of all metabolites [17]. However, the striking effect of the putative high-affinity enzyme (enzyme-2) on production of MA is more intriguing. Our results suggest that enzyme-2 favored the ring-opening pathway which leads to MA (see Figure 1) rather than the ring-hydroxylation pathways, leading to $\mathrm{PH}, \mathrm{HQ}$, and CA. This finding is consistent with a study by Weisel et al. [29], who reported that the fractional excretion of MA was greater in 4 subjects experimentally exposed to $40 \mathrm{ppb}^{13} \mathrm{C}$ benzene than had been reported in studies of workers exposed to benzene at ppm air concentrations. Predicted molar concentrations of MA and PH from the respective 2-enzyme models (Table 1) were as follows: $\mathrm{MA} / \mathrm{PH}=0.37$ at $0.001 \mathrm{ppm}, \mathrm{MA} / \mathrm{PH}=0.31$ at $0.01 \mathrm{ppm}$, $\mathrm{MA} / \mathrm{PH}=0.16$ at $0.1 \mathrm{ppm}$, and $\mathrm{MA} / \mathrm{PH}=0.12$ at $1 \mathrm{ppm}$. This further illustrates the diminishing role played by the high-affinity enzyme- 2 in benzene metabolism as air concentrations increased from ppb to ppm levels.

We recognize that levels of the benzene metabolites modeled in these analyses can be influenced by other saturable processes involving, for example, CYPs, epoxide hydrolases, and NQ01/MPO (see Figure 1) [16]. These interrelationships of multiple enzymatic processes clearly complicate the underlying toxicokinetics and suggest that some of the variability observed in our data could reflect interactions across saturable pathways. However, logic would argue that such interactions would tend to obscure rather than 
accentuate statistical evidence favoring the 2-enzyme model that we identified for MA and $\mathrm{PH}$. On the other hand, the lack of statistical evidence supporting the 2-enzyme model for HQ and CA could have been influenced by complications associated with multiple metabolic systems.

\section{Conclusions}

In conclusion, our results provide extremely strong statistical evidence that benzene is metabolized to PH and MA via two enzymes rather than one enzyme, and that the putative high-affinity enzyme is active primarily below $1 \mathrm{ppm}$. Model predictions further suggest that the ring-opening pathway, which leads to MA, is favored by the high-affinity enzyme.

\section{Acknowledgments}

The authors are indebted to Dr. Mustafa Dosemici, who compiled some of the benzene exposure data used in this investigation, to Dr. Min Shin, who helped assemble a portion of the database, and to Dr. Richard Hayes who assisted with conduct of the Shanghai portion of our study.

Funding Sources: This research was supported by the National Institute for Environmental Health Sciences through grants P42ES05948 and P30ES10126 (S.M.R.) and R01ES06721 and P42ES04705 (M.T.S.) and by funds from the intramural research program of the NIH, National Cancer Institute.

\section{Abbreviations and definitions}

$\triangle \mathrm{AIC}$

AIC

CA

CYPs

Evidence Ratio

HQ

MA

ppb

ppm

PH

SNP

SPMA

$w_{\text {better }}$ and $w_{\text {worse }}$

$X$

$X_{50}$, benzene concentration at which $Y$

$Y$

$Y_{0}$

$Y_{\max }$

$\hat{Y}_{x}$ and $\hat{Y}_{0}$ the difference in AIC values between two competing models Akaike's Information Criterion

catechol,

cytochrome P450 enzymes

ratio of the Akaike weights for the better model to the worse model

hydroquinone

$E, E$-muconic acid

parts per billion

parts per million

phenol

single nucleotide polymorphism

$S$-phenylmercapturic acid

Akaike weights for the better and worse of two competing models

air concentration of benzene (ppm)

$Y_{\max } / 2$

level of a given benzene metabolite $(\mu \mathrm{M})$

background level of $Y$

asymptotically maximum level of $Y$

predicted levels of $Y$ at $X$ and zero ppm, respectively 


\section{References}

1. IARC. Occupational exposures in petroleum refining, crude oil and major petroleum fuels. IARC Monogr Eval Carcinog Risks Hum. 1989; 45:1-322. [PubMed: 2664246]

2. Wallace L. Environmental exposure to benzene: an update. Environ Health Perspect. 1996; 104(Suppl 6):1129-1136. [PubMed: 9118882]

3. Infante PF, Rinsky RA, Wagoner JK, Young RJ. Leukaemia in benzene workers. Lancet. 1977; 19:407-421.

4. Rinsky RA, Smith AB, Hornung R, Filloon TG, Young RJ, Okun AH, Landrigan PJ. Benzene and leukemia. An epidemiologic risk assessment. N Engl J Med. 1987; 316:1044-50. [PubMed: 3561457]

5. Hayes RB, Yin SN, Dosemeci M, Li GL, Wacholder S, Travis LB, Li CY, Rothman N, Hoover RN, Linet MS. Benzene and the dose-related incidence of hematologic neoplasms in China. Chinese Academy of Preventive Medicine--National Cancer Institute Benzene Study Group. J Natl Cancer Inst. 1997; 89:1065-1071. [PubMed: 9230889]

6. Lan Q, Zhang L, Li G, Vermeulen R, Weinberg RS, Dosemeci M, Rappaport SM, Shen M, Alter BP, Wu Y, Kopp W, Waidyanatha S, Rabkin C, Guo W, Chanock S, Hayes RB, Linet M, Kim S, Yin S, Rothman N, Smith MT. Hematotoxicity in workers exposed to low levels of benzene. Science. 2004; 306:1774-1776. [PubMed: 15576619]

7. Ross D. Metabolic basis of benzene toxicity. [Review] [82 refs]. European Journal of Haematology Suppl. 1996; 60:111-118.

8. Snyder R. Benzene and leukemia. Crit Rev Toxicol. 2002; 32:155-210. [PubMed: 12071572]

9. Smith MT. The mechanism of benzene-induced leukemia: a hypothesis and speculations on the causes of leukemia. Environ Health Perspect. 1996; 104(Suppl 6):1219-1225. [PubMed: 9118896]

10. Bleasdale C, Kennedy G, MacGregor JO, Nieschalk J, Pearce K, Watson WP, Golding BT. Chemistry of muconaldehydes of possible relevance to the toxicology of benzene. Environmental Health Perspectives. 1996; 104(Suppl 6):1201-1209. [PubMed: 9118894]

11. Kim S, Vermeulen R, Waidyanatha S, Johnson BA, Lan Q, Smith MT, Zhang L, Li G, Shen M, Yin S, Rothman N, Rappaport SM. Modeling human metabolism of benzene following occupational and environmental exposures. Cancer Epidemiol Biomarkers Prev. 2006; 15:22462252. [PubMed: 17119053]

12. Qu Q, Shore R, Li G, Jin X, Chen LC, Cohen B, Melikian AA, Eastmond D, Rappaport S, Li H, Rupa D, Waidyanatha S, Yin S, Yan H, Meng M, Winnik W, Kwok ES, Li Y, Mu R, Xu B, Zhang $\mathrm{X}, \mathrm{Li}$ K. Validation and evaluation of biomarkers in workers exposed to benzene in China. Res Rep Health Eff Inst. 2003:1-72. discussion 73-87.

13. Rappaport SM, Yeowell-O’Connell K, Smith MT, Dosemeci M, Hayes RB, Zhang L, Li G, Yin S, Rothman N. Non-linear production of benzene oxide-albumin adducts with human exposure to benzene. J Chromatog B. 2002; 778:367-374.

14. Rappaport SM, Waidyanatha S, Yeowell-O'connell K, Rothman N, Smith MT, Zhang L, Qu Q, Shore R, Li G, Yin S. Protein adducts as biomarkers of human benzene metabolism. Chem Biol Interact. 2005; 153-154:103-109.

15. Kim S, Vermeulen R, Waidyanatha S, Johnson BA, Lan Q, Rothman N, Smith MT, Zhang L, Li G, Shen M, Yin S, Rappaport SM. Using urinary biomarkers to elucidate dose-related patterns of human benzene metabolism. Carcinogenesis. 2006; 27:772-881. [PubMed: 16339183]

16. Kim S, Lan Q, Waidyanatha S, Chanock S, Johnson BA, Vermeulen R, Smith MT, Zhang L, Li G, Shen M, Yin S, Rothman N, Rappaport SM. Genetic polymorphisms and benzene metabolism in humans exposed to a wide Range of air concentrations. Pharmacogenet Genomics. 2007; 17:789801. [PubMed: 17885617]

17. Rappaport SM, Kim S, Lan Q, Vermeulen R, Waidyanatha S, Zhang L, Li G, Yin S, Hayes RB, Rothman N, Smith MT. Evidence that humans metabolize benzene via two pathways. Environ Health Perspect. 2009; 117:946-52. [PubMed: 19590688]

18. Rothman N, Bechtold WE, Yin SN, Dosemeci M, Li GL, Wang YZ, Griffith WC, Smith MT, Hayes RB. Urinary excretion of phenol, catechol, hydroquinone, and muconic acid by workers occupationally exposed to benzene. Occup Environ Med. 1998; 55:705-711. [PubMed: 9930093] 
19. Waidyanatha S, Rothman N, Li G, Smith MT, Yin S, Rappaport SM. Rapid determination of six urinary benzene metabolites in occupationally exposed and unexposed subjects. Anal Biochem. 2004; 327:184-199. [PubMed: 15051535]

20. Rothman N, Smith MT, Hayes RB, Li GL, Irons RD, Dosemeci M, Haas R, Stillman WS, Linet M, Xi LQ, Bechtold WE, Wiemels J, Campleman S, Zhang L, Quintana P, Titenko-Holland N, Wang YZ, Lu W, Kolachana P, Meyer KB, Yin S. An epidemiologic study of early biologic effects of benzene in Chinese workers. Environmental Health Perspectives. 1996; 104(Suppl 6):1365-1370. [PubMed: 9118921]

21. Vermeulen R, Li G, Lan Q, Dosemeci M, Rappaport SM, Bohong X, Smith MT, Zhang L, Hayes RB, Linet M, Mu R, Wang L, Xu J, Yin S, Rothman N. Detailed exposure assessment for a molecular epidemiology study of benzene in two shoe factories in China. Ann Occup Hyg. 2004; 48:105-116. [PubMed: 14990432]

22. Fustinoni S, Consonni D, Campo L, Buratti M, Colombi A, Pesatori AC, Bonzini M, Bertazzi PA, Foa V, Garte S, Farmer PB, Levy LS, Pala M, Valerio F, Fontana V, Desideri A, Merlo DF. Monitoring low benzene exposure: comparative evaluation of urinary biomarkers, influence of cigarette smoking, and genetic polymorphisms. Cancer Epidemiol Biomarkers Prev. 2005; 14:2237-44. [PubMed: 16172237]

23. Ghittori S, Fiorentino ML, Maestri L, Cordioli G, Imbriani M. Urinary excretion of unmetabolized benzene as an indicator of benzene exposure. J Toxicol Environ Health. 1993; 38:233-43. [PubMed: 8450555]

24. Ghittori S, Maestri L, Fiorentino ML, Imbriani M. Evaluation of occupational exposure to benzene by urinalysis. Int Arch Occup Environ Health. 1995; 67:195-200. [PubMed: 7591178]

25. Waidyanatha S, Rothman N, Fustinoni S, Smith MT, Hayes RB, Bechtold W, Dosemeci M, Li G, Yin S, Rappaport SM. Urinary benzene as a biomarker of exposure among occupationally exposed and unexposed subjects. Carcinogenesis. 2001; 22:279-286. [PubMed: 11181449]

26. McDonald TA, Holland NT, Skibola C, Duramad P, Smith MT. Hypothesis: phenol and hydroquinone derived mainly from diet and gastrointestinal flora activity are causal factors in leukemia. Leukemia. 2001; 15:10-20. [PubMed: 11243376]

27. Kettl S. Accounting for heteroscedasticity in the transform both sides regression model. J Royal Stat Soc Ser C (Appl Stat). 1991; 40:261-268.

28. Burnham, KP.; Anderson, DR. Model Selection and Multimodel Inference: A Practical Information-Theoretic Approach. 2. Springer; New York, NY: 2002.

29. Weisel CP, Park S, Pyo H, Mohan K, Witz G. Use of stable isotopically labeled benzene to evaluate environmental exposures. J Expo Anal Environ Epidemiol. 2003; 13:393-402. [PubMed: 12973367] 


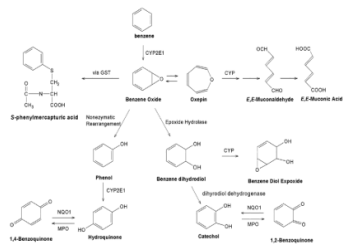

FIGURE 1.

Simplified metabolic scheme for benzene showing major pathways and metabolizing genes. 


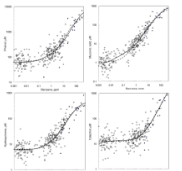

FIGURE 2.

Scatter plot of levels of benzene metabolites (in clockwise order: phenol, muconic acid, catechol, and hydroquinone) versus the level of benzene in air for 263 nonsmoking female subjects. Open points represent subjects from Tianjin and closed points represent subjects from Shanghai. The dashed curve represents the benzene metabolite level predicted under the 1-enzyme model (Eq. 1) and the solid curve represents the benzene metabolite level predicted under the 2-enzyme model (Eq. 2). 


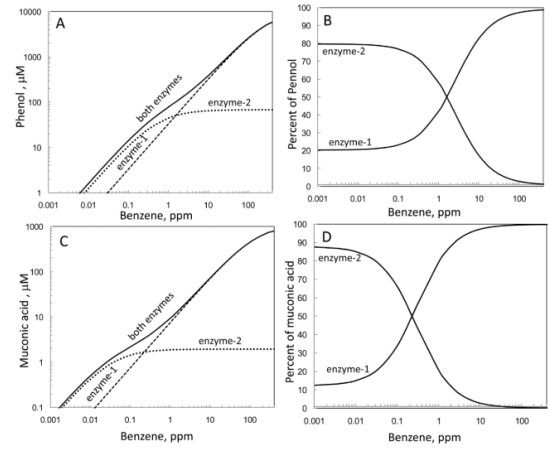

FIGURE 3.

Contributions of two metabolizing enzymes toward production of phenol (top) and muconic acid (bottom), predicted under the 2-enzyme model at increasing air concentrations of benzene. (A) and (C): Predicted background-adjusted mean trends for phenol (A) and muconic acid (B) attributed to enzyme-1, enzyme-2, and both enzymes (sum of enzyme-1 and enzyme-2). (B) and (D): Percentages of phenol (B) and muconic acid (D) attributed to enzyme-1 and enzyme- 2 . 


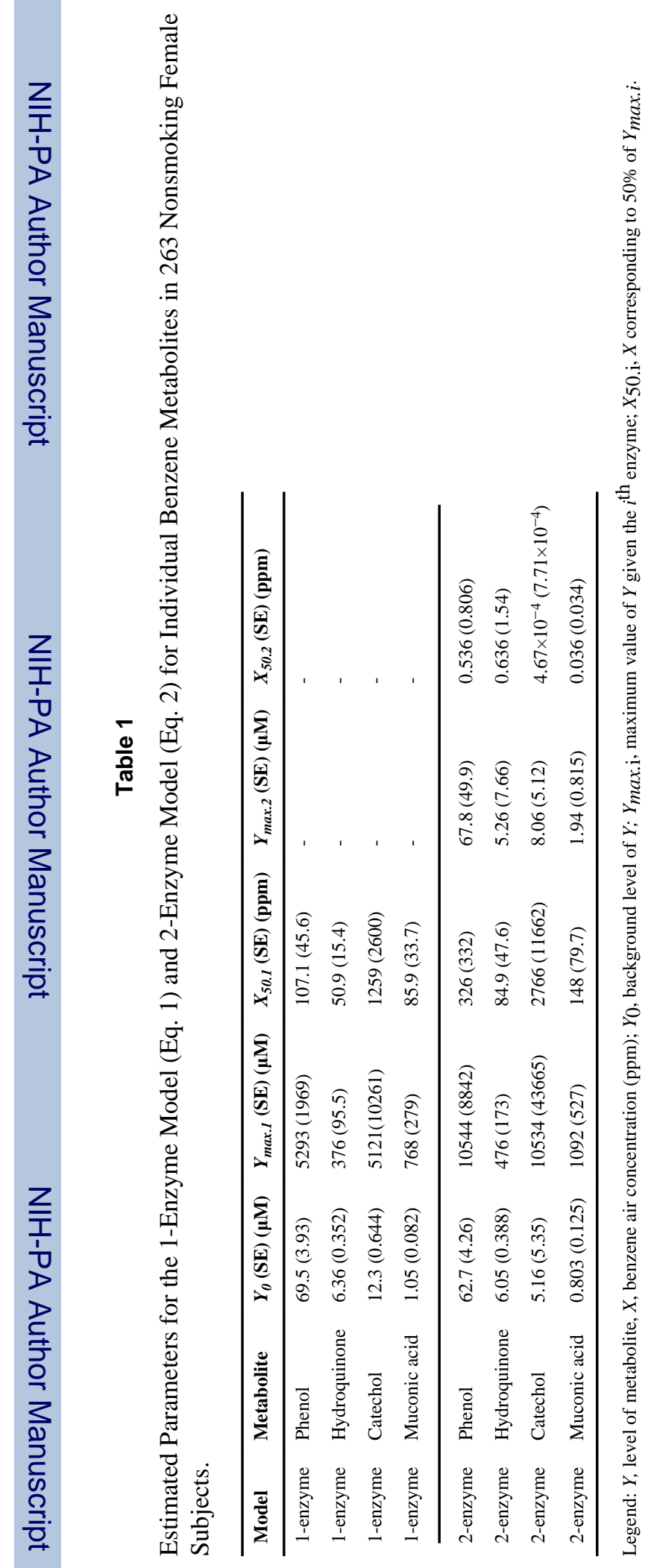




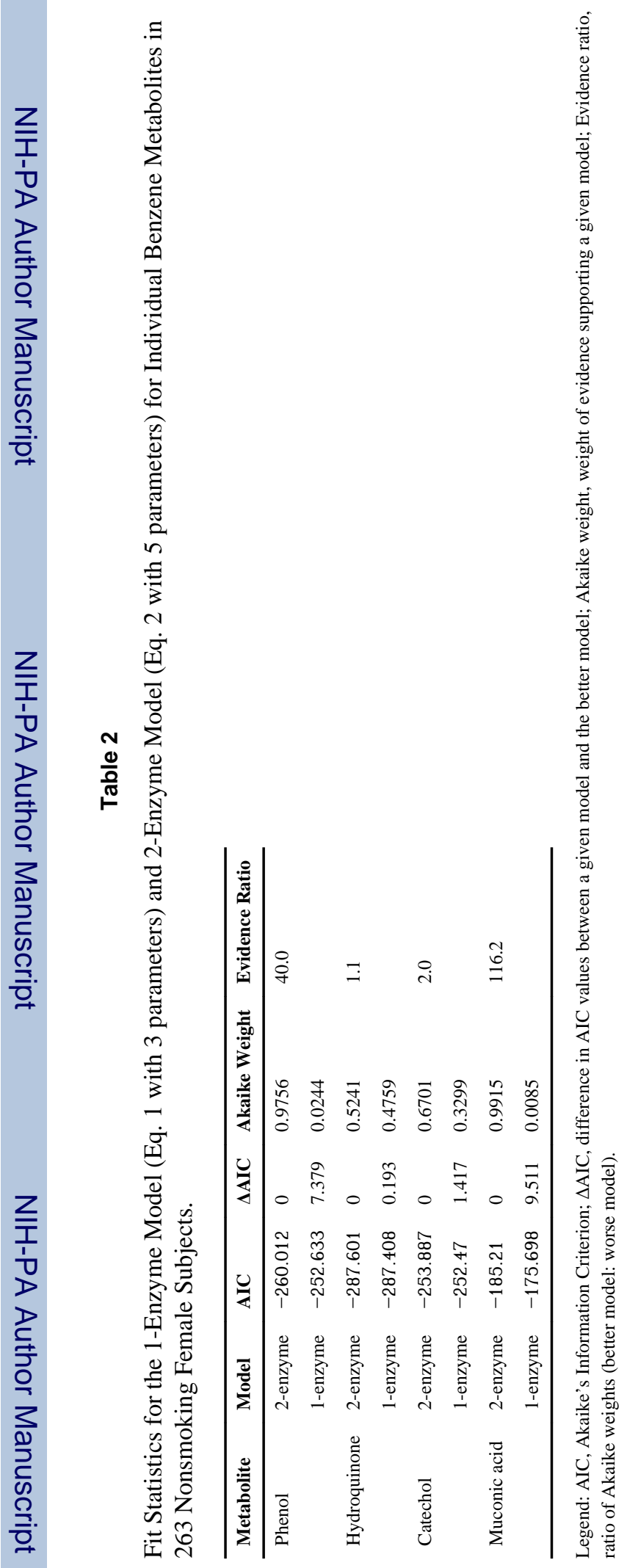

